\title{
Re-Contextualizing Vocational Didactics in Norwegian Vocational Education and Training
}

\author{
Hæge Nore \\ Oslo and Akershus University College of Applied Sciences \\ Faculty of Education and International Studies \\ Department of Vocational Teacher Education \\ PO box 4 St. Olavs plass, NO-0130 Oslo, Norway \\ Email: haege.nore@hioa.no
}

\begin{abstract}
This article explores teachers and trainers didactical practices in different contexts in Norwegian VET: schools and workplaces. With the introduction of e-resources and e-portfolios in VET, learners as well as teachers and trainers experience a more hybrid learning-arena, which claims for a recontextualization of vocational didactics as well as re-defining roles and responsibilities of the actors. The article discuss new forms of boundary crossing, dealing with e-portfolios as boundary objects, increasing learner autonomy, transformative learning outcomes, interaction between actors and designing learning processes in hybrid learning-arenas. Vocational didactics as understood in a teacher-training context are challenged by more actors and new forms of interactivity with technological tools crossing sites. The study is based on a longitudinal study in a national project on quality assessment, interviews with teachers and trainers as well as apprenticeship training offices supported by documentary evidence from three trades: sales, plumbing and industrial mechanics.
\end{abstract}

Keywords: Vocational Didactics, Hybrid Learning, Re-Contextualization, Boundary Crossing, Teachers and Trainers, Vocational Education and Training

\section{Bibliographical notes:}

Hæge Nore is an Associate Professor at the Department of Vocational Teacher Education at the Oslo and Akershus University College of Applied Sciences, Norway. Her research interests include vocational education and training, workplace learning, hybrid learning, assessment in VET and the training of trainers. 


\section{Introduction}

Vocational didactics has been part of vocational teacher training in Norway since the late 1990s and counts as 30 ECTS. Vocational didactics is closely linked to the challenges that teachers meet in the vocational education and training (VET) system in Norway, which is an alternating dual system conducted in both schools and enterprises. The main model is two years as a student in upper secondary school followed by two years of apprenticeship in public or private training enterprises.

New perspectives were brought into vocational didactics with the latest reform in 2006 (the Knowledge Promotion). Teachers had to deal with a wide range of trades in broad entrances to VET, and at the same time cooperate with enterprises and integrate more work-based learning into the school-based part of VET. In addition, new curricula were introduced, defining common competence goals for the school-based and company-based part of VET, as teachers and trainers have to develop local plans adapted to the students' preconceptions and local conditions. In the years to come, there will be flexible pathways through VET, thereby strengthening the work-based part from an early stage and, as such, the roles of trainers.

This article draws upon data from a broad project on quality assessment in VET (Høst 2015), in which different areas, levels and actors in the Norwegian VET system were examined through a longitudinal study from 2012-2015. Data are used to raise questions on what vocational didactics means for teachers, trainers and apprenticeship training offices. From a traditional perspective, vocational didactics belongs to vocational teacher training and consequently, higher education. This article discuss vocational didactics in relation to the changing roles of teachers, trainers and apprenticeship training offices as they enter into a more hybrid learning arena for students. Hybrid learning arenas came to the fore through the project on quality assessment and will further be elaborated on. Based on this study and hybrid learning, I will introduce new challenges for teachers and trainers as a re-contextualization of vocational didactics.

\section{Vocational Didactics - a Concept for Higher Education?}

Vocational didactics is closely linked to the development of professional practice in specific trades, with a direct link between professional, authentic work tasks and requirements and vocational teacher training. Students enter vocational teacher training with occupational qualifications and at least three years of experience as skilled workers in a trade. During the teacher training, they further develop their vocational skills and knowledge, combining them with pedagogical and didactical skills and knowledge. We call it vocational teachers' double competences, as both skilled workers in a trade and as vocational teachers.

Since the 1990s, vocational didactics has been a central part of vocational teacher education in Norway. Hiim and Hippe (2001) defined it as "practicaltheoretical planning, implementation, assessment and critical analyses of tradespecific learning processes in schools and workplaces." This definition is also incorporated in the national guidelines for the three-year bachelor vocational teacher education (UHR 2006). "Vocational didactics deals with learning activities connected to learning a trade. Vocational didactics should elaborate the candidates' qualifications to didactic planning, teaching, assessing and critical analysis of learning processes." Vocational didactics should be consistently throughout all 
teacher education and counts for 30 ECTS both in a bachelor education and in the one-year practical pedagogical vocational teacher education.

Nilsen and Haaland (2013) stress even more the professional practice as the basis for learning processes. They also remind teachers to be aware of their responsibility to develop students' relevant skills and knowledges for future working life.

Through teacher education, teachers learn to interpret and understand the curricula, and the planning of sessions and assessments according to curricula. Their responsibility is limited to school workshops and classrooms, except for the assessment of a new subject called the In-depth Study Project (IdSP) often conducted in enterprises. As students find flexible pathways through VET, including more work-based learning from an early stage, networking between teachers, trainers and apprenticeship training offices becomes more important.

There are no requirements for vocational didactics in the training of trainers, not even requirements for training at all. On the other side, all regional authorities offer short (two days) training of trainer courses, and several books and online resources are available (Nilsen and Nore 2001/2005; Djupvik and Haaland 2015; NHO 2007/2013; Halland and Nore 2010). Courses and resources cover topics such as: (1) learning at the workplace, (2) the planning of learning processes through daily work, (3) apprentices' preconditions, (4) facilitation, guidance and support, (5) feedback, assessment and documentation, (6) preparation for trade and journeyman's examinations, and (7) networking. In the context of trainers and work-based learning, vocational didactics is not a concept in use.

What implications does a restructuring of Norwegian VET have on vocational didactics, and what does vocational didactics mean to the different actors in VET?

\section{$3 \quad$ VET Structure, Roles and Responsibilities}

As already mentioned, the Norwegian VET is an alternating dual system conducted in schools and enterprises, including two years of school-based training in upper secondary school and two years of work-based training in an approved public or private training enterprise. Vocational teachers are responsible for the school-based part, whereas for the work-based part there is a shared responsibility between experienced skilled workers as trainers and apprenticeship training offices.

Because of the broad entrances into VET, The Knowledge Promotion introduced a new subject called the In-depth Study Project (IdSP). IdSP should primarily take place in training companies as a specialization in a specific trade with a relevant vocational practice. Still, it is part of the school-based training and teachers are responsible, even though many in-company trainers are also involved. The IdSP is a hybrid subject, cutting across the institutional division of school and work, and as a reform element, it can be seen as a compromise that carries inherent tensions and dilemmas which must be resolved at the local level by vocational teachers and trainers.

As students enter apprenticeship, they quit the school and the teachers, with most of them (75-80\%) signing a training contract with an apprenticeship training office. The rest sign contracts directly with approved training establishments. After the in-company training of apprentices became part of the formal education system in 1994, a number of apprenticeship training offices were established. The offices are approved training establishments and are responsible for a two-year training contract with apprentices. The offices are owned and driven by a community of companies. The training of apprentices has become a shared responsibility between 
the company, where learning takes place, and the apprenticeship training office. Thus, the roles and responsibilities of trainers and training offices are always on the move.

Flexible pathways have an alternating work-based and school-based VET and claims for cooperation and communication between the actors, while apprenticeship training companies have taken roles and responsibilities for coordinating IdSP and other models for combining work-based and school-based learning. Moreover, they are also active in recruiting apprentices and securing the transition from school to apprenticeship (Høst et al. 2014).

\section{$4 \quad$ Data and Method}

The research to be discussed here was part of a longitudinal qualitative study that followed 115 students from the second year in school in the spring of 2012, via two year of apprenticeship, to their trade or journeyman's examination in the autumn/winter of 2014/2015.

A strategic quota sampling was made in three different trades: sales, plumbers and industrial mechanics. Plumbing has a long tradition, a strong identity and formal authorization schemes that clearly influence their education and training. Students enter VET in plumbing through a vocational program in building and construction, and continue through the second year together with tinsmiths and roofers, before entering apprenticeship in plumbing. Industrial mechanics and similar vocations undergo continuous changes, and recruit to a wide range of workplaces in larger companies. Students enter VET through a technical and industrial production program covering 59 trades. They continue the second year with industrial technology covering 23 industrial trades, before entering apprenticeship in industrial mechanics. Sales do not have the same tradition for skilled workers, and the formal education and training of salespersons is relatively new in Norwegian VET. Students enter VET through the program service and transport and continue in the second year together with office and administration workers and security guards, before entering an apprenticeship in sales.

The sample also represents three counties across Norway, with various occupational cultures and training traditions. One county has traditions linked to forestry and agriculture, with a relatively low educational level. One county has traditions going back to hydropower and energy-intensive industry, as well as a high number of skilled workers and engineers, while the third county represents the oil industry and their subcontractors. The interest for VET and the number of skilled workers is high, as is the general educational level.

The cross-cutting theme of the broader project was on quality assessment in VET and was funded by The Norwegian Directorate for Education and Training (Høst 2015). The project examined the actual quality in different areas in Norwegian VET. Another aspect in the project was how different stakeholders were dealing with quality improvement. The project consisted of four sub-themes: 1) learning environments, completion and dropout, 2) content and assessment practices, 3) quality assurance, quality management and quality assessment, 4) VET as a gateway to employment.

This article is based on research related to sub-theme 2, and concentrates on teachers, trainers and training offices' practical didactical thinking, as well as their practices, in addition to data drawn from the first and second phase of the longitudinal study: 1) after two years of school-based VET and, 2) after one-and-ahalf years of apprenticeship. The analyses are based on semi-structured interviews 
with 25 vocational teachers and 15 department heads (vocational program) in the first phase, and 41 trainers and 11 training offices in the second phase.

The interview data were validated and elaborated on by documentary evidence from local training plans, task descriptions, test tasks, reports, assessment schemes and e-portfolios. The data was analyzed according to how the different respondents use the curricula, how they plan and organize content and progression in learning processes and how they establish assessment practices.

The use of learning management systems (LMS) in the school-based part of VET and the extensive use of E-portfolios in the apprenticeship period opened up new dimensions in the study, not to mention the role of the system developers and the cooperation between the developers and the different actors in VET, along with the impact of using LMS and E-portfolios on teachers and trainers practices and the apprentices learning processes.

\section{Teacher and Trainer Practices}

Teachers and trainers were asked to explain and show local training plans, a choice of learning tasks and assessment schemes. They also reflected upon the development processes, possible tensions and students' or apprentices' career plans and suitability for actual or similar trades. In Norway, there is a local responsibility to adapt the curriculum to students' preconditions and career plans, as well as the needs of the local industry and working life (Regulation to the Education Act 2006).

\subsection{Teachers in a School-based VET}

In the first phase of the project, we focused on the second year of school-based training, and looked into how teachers in different vocational programs work together with the heads of departments and representatives from the work-based part of VET. The study included processes interpreting curricula, defining content, learning tasks and assessment practices, as teachers have reported a wide range of practices, both between schools and between educational programs and trades (Nore and Lahn 2013).

Within sales and service, we found a strict loyalty to the curriculum and written learning material. The learning plans reflected the curriculum, and were even divided into program subjects as listed in the curriculum, with separate teachers. Learning primarily took place in classrooms, including IdSP, with the latter conducted as youth enterprises/entrepreneurship. Assessment practices were linked to learning outcome descriptions. Teacher practices in sales reflect the short experience with sales as part of the formal education system and teachers without a trade certificate or practical experience in the field. In addition, the networks often consist of teachers and training offices, and not skilled workers or trainers as company representatives.

Within industrial technology and for plumbers, there were more examples on common processes with interpretations of curricula, discussions on relevant tasks and the development of joint assessment schemes. Local networks with teachers, companies, training offices and branch organizations on a regional level are common both within the industrial area and within building and construction. The collective processes started with the implementation of the Knowledge Promotion, but have ceased in favor of a more flexible and local approach to teaching and training. The learning arena for IdSP could be either schools or enterprises. The main model was IdSP in enterprises, but we also found examples where teachers 
chose to keep the students in a school workshop, especially when the teacher himself had a relevant trade or a journeyman's certificate. Furthermore, teachers argued that some students were too immature for a real working life.

Teachers put a great amount of attention on students' preconceptions, and emphasized individualized training and feedback. For all trades, teachers reported on too many low achievers, who had no possibility to attain an apprenticeship or trade certificate in the long run. They struggled to hinder dropouts, while at the same time challenging students with potential.

In the school-based part of VET, teachers experienced more elements and challenges than ever before. In addition to the traditional training in school workshops and classrooms, there are IdSP and other internship periods in enterprises, and an extended use of LMS both for documentation and as an assessment tool for half-year appraisals. Vocational teachers also abstaining from the use of LMS due to the distance from practical work. Moreover, LMS will not function as a cooperation tool between teachers and enterprises since the enterprises (or other stakeholders outside the school system) do not have access to the LMS. LMS are often designed according to teaching and learning in general subjects. Nevertheless, the school-based part of Norwegian VET still seems somewhat separated from the work-based part, even though all stakeholders underscore a holistic VET from the first year in school via an apprenticeship, to trade examinations at the end.

The teachers did not mention vocational didactics as a concept, but they all talked of planning work tasks and student progression, guidance to students, giving feedback, organizing cooperation between teachers and with companies. In some ways, we experienced the teachers' practices as similar to "laissez-faire localism", as described by Hodgson and Spours (2012). Teachers argue why they do not utilize the local scope for action: "The students we have, the resources and equipment we have and the teachers competencies don't give us much choice.”

\subsection{Trainers and Training Offices}

In the second phase of the study, we focused on the two years of work-based training, and looked into how training establishments and apprenticeship training offices work together on defining content and curriculum, as well as establishing assessment practices for apprentices. Data were analyzed according to how the different respondents used the curricula, how they planned and organized the progression in the learning processes and how they developed assessment practices. How do companies, apprentices and training offices interact and shape good learning processes? Our analytical approach was iterative in the sense that unexpected findings were springboards for a recoding and redesign of the empirical framework. The extensive use of e-portfolios in the apprenticeship period opened up new dimensions in the study, including the role of the system developers, the cooperation between the training offices and system developers and the impact of using e-portfolios on the apprentices learning processes (Nore and Lahn 2014a).

As for the use of e-portfolios, we found few differences in the pedagogical design between training offices in the same branch using the same e-portfolio system. Small differences were found among industrial mechanics due to the flexibility in the e-portfolios used, a system that triggers tailor-made training and cooperation between training offices, training establishments and apprentices. Most of the e-portfolio systems are designed to combine work performed with learning outcomes as described in the curricula. Some systems used by plumbers and 
industrial mechanics opened up the possibility for documenting core tasks and competences in the trade.

The companies and apprentices in the study regarded e-portfolios as a quality instrument, a tool to secure training and learning according to the curriculum and expected learning outcomes. Companies also regarded the e-portfolio as local training plans and even assessment schemes when used in the obligatory half-year appraisals. As such, the introduction of e-portfolios and the role of training offices as quality managers remove the responsibility from the companies and trainers. As a result, local training plans and assessment schemes were unusual except for the big companies. Nevertheless, trainers organized training, found appropriate learning tasks and gave feedback to the apprentices on the work they performed. Training offices and trainers described in a way two different and parallel learning systems: 1) work-based learning and 2) curriculum-based learning (Nore and Lahn 2014b). In many ways the parallel learning system contrasts performance goals and learning goals, in addition to two different training schemes as shown in other studies (Dweck 1986; Kirpal 2010).

An increasing complexity with inherent tensions in the work-based part of Norwegian VET challenges all stakeholders. 1) Apprentices are dealing with fragmented and different learning resources in a tension between work-based and curriculum-based learning. 2) Trainers are responsible for quality of performed work, as well as facilitating apprentices on their way to trade examinations in accordance with curricula. 3) Apprenticeship training offices in-between the regional authorities with state regulations, work-based learning in the companies and apprentices' individual learning paths. 4) E-portfolio system developers with a loyalty to learning outcomes as described in curricula or a system suitable for communication and cooperation across sites. 5) Developers of e-resources (branch organizations, private institutions and institutions owned by regional authorities) with different interests and perceptions on VET; and 6) Course providers often aiming for complex target groups, and not only apprentices.

The complexity in the work-based part of Norwegian VET also indicates different understandings of vocational didactics.

\section{A Hybrid Learning Arena}

New perspectives on both teaching and learning in Norwegian VET can be seen throughout the study, as the traditional 2+2- model gradually changes to a more hybrid learning (and teaching) arena. From an early stage in VET, students cross boundaries between schools, workplaces and courses offered by specialized course providers, with the latter meeting schools' and companies' lack of updated or specialized knowledge and skills. Additionally, e-resources are available that combine practical work in school workshops and workplaces with relevant theory. In VET, this means more than hybrid learning, as explained by Mossavar-Rahmani and Larson-Daugherty (2007) as a combination of online and on-site courses in general subjects and higher education.

The increasing emphasis on both work-related and learning-related documentation has inspired developers of e-portfolios to support learners, teachers and trainers to build a new arena for cooperation across arenas and actors in VET. Figure 1 shows the complexity of different learning arenas and actors in Norwegian VET: 


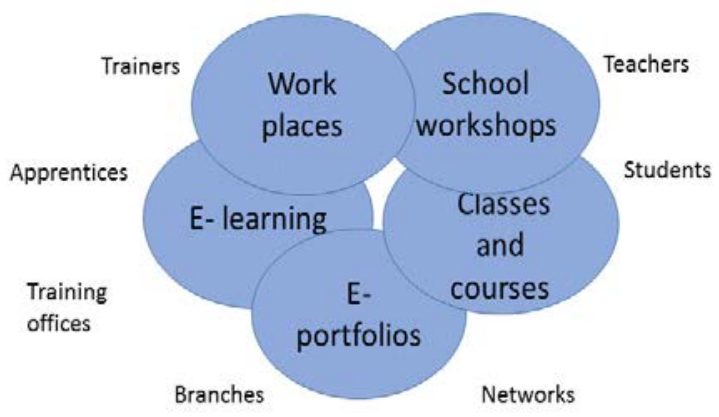

\section{Figure 1: A hybrid learning arena}

Through this model, we can easily define different contexts in which VET is conducted. A hybrid learning arena challenges teachers, trainers and training offices and resource developers to re-think their pedagogical design, insofar as how to utilize the best of the different arenas, and how to secure progression for the individual on their way to becoming a skilled worker. Again, the challenges for teachers with hybrid learning are described for general teachers (Reynard 2007), and our study challenges us to do the same for an even more complex arena.

From general didactics, we can also draw on Schulman's idea (1986) of pedagogical content knowledge (PCK), further developed by Mishra and Koehler (2006), to include technology. The technological pedagogical content knowledge (TPACK) presents a dynamic framework describing teachers' skills and knowledge. These frameworks inspire teachers to re-think their practices and re-design, implement and evaluate curriculum and learning with technology.

Looking at VET as a hybrid learning arena from the start to trade examinations means that learners, teachers, trainers and training offices are all working across the arenas, and are equally responsible for continuous improvement and development of VET.

\section{Hybrid Learning Arenas: Challenges for Teachers and Trainers}

With a move to more hybrid learning in both the school-based and work-based part of VET, there are many challenges to teachers and trainers in designing teaching and learning, and to re-think practices and roles.

\subsection{Boundary Crossing}

A hybrid learning arena also means crossing boundaries between different arenas, for students and apprentices, as well as teachers, trainers and training offices. Traditionally, as in The Apprentice Survey each year, the authorities question the transfer of learning - the effect of school-based knowledge on work-based learning and performing authentic work tasks in enterprises, whereas teachers ask the same of students after periods of IdSP in enterprises. The surveys request how students can transfer what is learned in an enterprise to performance in school; with the main question being how something learned in one task or context applies to another task or context.

Several studies on boundary crossing (Engeström 2001; Thuomi-Gröhn, Engeström and Young 2003; Konkola et al. 2007; Akkermann and Bakker 2011) question the effect of transfer between school and work, and ask for new ways of 
collaboration between schools and workplaces in which the aim is to create new knowledge and practices in cooperation. There is an appreciation of variety in which all actors will enter unfamiliar territories, and to some extent, they might be unqualified. Mixing different practices in a hybrid learning arena may open up new spaces that allow a negotiation of meaning and establish new forms of communication. Such cognitive processes carry a potential for learning, not only for students and for apprentices.

Boundary crossing individuals such as VET students and apprentices, teachers, trainers and training offices run the risk of not being accepted. Learning-arenas are different and a "boundary-crossing competence," meaning the ability to manage and integrate multiple, divergent discourses and practices across boundaries are needed. (Walker and Nocon 2007).

\subsection{E-portfolios as Boundary Objects?}

E-portfolios could be characterized as an artefact fulfilling a bridging function between boundaries and intersecting practices (school, work, e-resources and external courses). E-portfolios are made to track student development as experienced by the individual, while at the same time checking across learning outcomes according to curricula. This is in accordance with the ambiguity of boundary objects as described by Akkermann and Bakker (2011). On the one hand, they articulate meaning and address multiple perspectives, whereas on the other they have a structure that is common enough to make them recognizable across worlds. They should be plastic enough to adapt to local needs, yet robust enough to maintain a common identity, structured weakly in common use and strongly structured in individual use.

E-portfolios enable communication and collaboration across learning arenas in VET, and may include all actors in VET. In our study, we found some eportfolios more like LMS in the school context and acting as control instruments of learning outcomes. As such, they are not boundary objects. In contrast, we found examples of e-portfolios that enabled students and apprentices to document and articulate their learning in different arenas, and at the end linking what they learned to the local adaption of the curriculum.

The school and workplaces may engage in a collaborative interaction in ways that foster mutual learning. According to this perspective, what is transferred is not a fixed package of skills and knowledge that remain intact through the process (Hinrichs 2014). Instead, skills and knowledge are actively being interpreted, modified and reconstructed in the process. In our study, e-portfolios was of main interest for the training offices, while teachers and trainers reported low levels of activity. There is a way to go for e-portfolios as mediators for communication and collaboration across sites (Nore and Lahn 2014b)

\subsection{Increasing Learner Autonomy}

Students and apprentices in a hybrid learning arena are co-designers of their VET, as they choose trades and places for both IdSP and training enterprises. Their use of E-resources and external courses are also part of the design. Learning tasks in a company are neither predictable nor standardized. Hybrid learning requires an increasing learner autonomy, as the learners are the only ones to know what they are performing and learning in the different arenas, and how the different parts assist the development of vocational identity and pride. Students and apprentices 
know better when and how they need their teacher/trainer, and could ask for more direct intervention. They are also responsible for using e-portfolios to help secure a foundation for communication and cooperation with fellow students, teachers and trainers, as well as training offices. Consequently, they act as brokers between different cultures in school-based and work-based training (Wenger 1998; TuomiGröhn, Engeström and Young 2003). Students become more active and responsible in their learning processes if they can meet and talk with teachers, trainers and training offices. Further explication of skills and competences are needed for cooperation and discussions. On the other hand, teachers and trainers are challenged in their role as brokers or boundary workers not being too aligned with one system (curriculum) or another system (work-based).

\subsection{Content Choice and Transformative Learning Outcomes}

Throughout the learning process in a hybrid learning-arena, content is worked on, developed and applied by the learner. This is not only the case with hybrid learning. The content in VET are continuously developing through changing demands, technology and expanding markets in different vocations (Heinz 2009), which also makes the interpretation and implementation of curricula a continuous process. When content is linked to practical work, customers and markets in training enterprises as well as unlimited Internet resources, learner may experience curriculum as irrelevant or out of date. Curriculum defined outcomes are challenged. Heinz (2009) ask whether it is possible to develop and maintain a vocational identity in a world of deregulated labour markets, multi-skilled jobs and flexible employment. He concludes that in flexible work environments, the perception of past, present and future must be guided by biographical reflections. Reflections is also one of the learning mechanisms that can take place at boundaries (Akkermann and Bakker 2011).

\subsection{Increased Interaction between Actors}

There are many actors in a hybrid and complex learning arena. Throughout the four years in VET, students will meet many teachers and trainers, as well as representatives from training offices, fellow students and communities of workers. The teacher's role as an expert, organizer, motivator, mentor and assessor has to be revised with students' expansive practices and the new communities of actors in VET (Nore 2010; Edwards 2011). Networks including teachers, trainers and training offices are established in most regions, but have more teachers than trainers and often work to meet requirements of the regional authorities. Through networks across sites, teachers and trainers will learn and change through the networking solving the many dilemmas with a hybrid learning-arena (Veugelers and O'Hair, 2005). Such networks will also be in accordance with what Hodgson and Spours (2012) call "democratic localism" which leads to "local learning ecology"; a more flexible and sustainable VET based on committed cooperation.

But as long as network meetings are on-site whilst the forthcoming communication and cooperation will include interactions and student involvement through e-portfolios, they will not be border crossers or brokers.

\subsection{Designing and Organizing Learning Processes}

Organizing and facilitating learning processes in a hybrid context seems to be more complex than traditional planning in schools and workplaces. As mentioned before, 
the learners are more autonomous, the learning outcomes transformative and the eportfolio as a boundary object claims for communication and cooperation across sites. There is a challenge for teachers and trainers to secure progression and higher-level cognitive apprenticeship through scaffolding. Ghefaili (2003) mention modeling, coaching, scaffolding, articulation, reflection, and exploration as ingredients for designing learning environments for cognitive apprenticeship. In scaffolding, teachers and trainers support students to manage more complex task performance up to the extent that they can handle. Scaffolding support students to be independent in their work performance. E-portfolios can play an important role to identify students' struggling with problem solving or understanding of complex work situations.

\section{Conclusions}

When a hybrid learning-arena came to the fore during our study, we had to re-think and re-contextualize vocational didactics. Traditionally we have talked of schoolbased and work-based VET, addressing vocational didactics to either teachers or trainers and to the necessity of working together on transfer and transitions between school and work. In our extended model (figure 1), we added technological tools and resources as well as external courses. There are more studies on hybrid learning as combining school-based (on-site) and on-line learning, especially in general subjects (Mossavar-Rahmani and Larson-Daugherty 2007; Reynard 2007). Other studies explore the use of LMS or e-portfolios, like Attwell and Costa (2009) introducing the learners' development of their own e-portfolios as education systems become more fragmented. Høst et al. (2012) studied eportfolios as a documentation tool from school-based VET to trade examinations, and found inconsistency between school and work and skepticism to the use value for learners as well as teachers and trainers.

The challenges for teachers and trainers mentioned in the previous section, claims for new practices and competencies for all actors in VET. The context for learning and teaching design are neither schools nor workplaces. In our model, we break down the traditional arenas and bring in e-portfolios as a didactical tool as well as a tool for learner autonomy and interaction between actors. Content as described in curricula are also challenged in this model, and will not function as a sufficient tool for didactical planning. E-portfolios based on a curriculum design do not meet these challenges. As discussed in the previous section, there are many pitfalls entering such a hybrid learning-arena. On the one hand, learners as well as teachers, trainers and training offices should be aware of the pitfalls. On the other hand, all actors should attain communities of practice across arenas together with learners to explore, reflect on and further develop the learners' processes on their way from day one to their trade or journeyman's certificates. 


\section{References}

Akkermann, S. F., \& Bakker, A. (2011). Boundary crossing and boundary objects. Review of educational research, 81(2), 132-169.

Attwell, G., \& Costa, C. (2009). Integrating personal learning and working Environments. Glasgow: The University of Strathclyde Institutional Repository. http://strathprints.strath.ac.uk/.

Djupvik, A.E., \& Haaland, G. (2014). Veileder- og instruktørhåndboka. Oslo: PEDLEX Norsk Skoleinformasjon.

Dweck, C.S. (1986). Motivational processes affecting learning. American Psychologist, 41(10), 1040-1048.

Engeström, Y. (2001). Expansive learning at work: Toward an activity theoretical reconceptualization. Journal of education and work, 14(1), 133-156.

Edwards, A. (2011). Learning how to know who. Professional learning for expansive practice between organizations. In S. Ludvigsen, A. Lund, I. Rasmussen, \& R. Säljö (Eds.), Learning across sites. New tools, infrastructures and practices (pp. 17-32). New York: Routledge.

Ghefaili, A. (2003). Cognitive apprenticeship, technology, and the contextualization of learning environments. Journal of Educational Computing, Design \& Online Learning, 4(1), 1-27.

Halland, G., \& Nore, H. (Eds.). (2010) Etterutdanningsmateriell for fag- og yrkesopplcering. (VET-Resources) Oslo: Utdanningsdirektoratet.

Heinz, W. (2009). Vocational Identity and Flexible Work: A Contradicting or Constructive Relation? In F. Rauner, E. Smith, U. Hauschildt, \& H. Zelloth (Eds), Innovative apprenticeships: promoting successful school-to-work transitions (pp. 35-47). Berlin: LIT.

Hiim, H., \& Hippe, E. (2001). A utdanne profesjonelle yrkesutøvere. Yrkesdidaktikkog yrkeskunnskap. Oslo: Gyldendal Akademisk.

Hinrichs, A.-C. (2014). Predictors of Collateral Learning Transfer in Continuing Vocational Training. International Journal for Research in Vocational Education and Training, 1(1), 35-56.

Hodgson, A., \& Spours, K. (2012). Three versions of 'localism': implications for upper secondary education and lifelong learning in the UK. Journal of education policy, 27(2), 193-210.

Høst, H., Skålholt, A., Nore, H., \& Tønder, A. H. (2012). Gjennomgående dokumentasjon, eller oppleringsboka i ny form? Evaluering av forsøket med gjennomgående dokumentasjon i fag- og yrkesopplceringen. Oslo: NIFU.

Høst, H., Skålholt, A., Reiling, R.B., \& Gjerustad, C. (2014). Opplaringskontorene i fag-og yrkesopplæringen - avgjørende bindeledd eller institusjon utenfor kontroll? NIFU Rapport 51/2014.

Høst, H. (Ed). (2015). Kvalitet i fag- og yrkesopplceringen. Sluttrapport. Oslo: NIFU-rapport14/2015, Fafo-rapport 2015:32, HiOA rapport 2015 Nr. 4.

Kirpal, S. (2010). Trainers' Changing Role and Continuing Learning in Different VET Systems: A Comparative Perspective. In F. Rauner, E. Smith, U. Hauschildt, \& H. Zelloth (Eds), Innovative apprenticeships: promoting successful school-to-work transitions (pp. 110-114). $2^{\text {nd }}$ Edition. Berlin: LIT.

Konkola, R., Tuomi-Gröhn, T., Lambert, P., \& Ludvigsen, S. (2007). Promoting learning and transfer between school and workplace. Journal of Education and Work, 20(3), 211-228. 
Mishra, P., \& Koehler, M. (2006). Technological pedagogical content knowledge: A framework for teacher knowledge. The Teachers College Record, 108(6), 1017-1054.

Mossavar-Rahmani, F., \& Larson-Daugherty, C. (2007). Supporting the hybrid learning model: A new proposition. MERLOT Journal of Online Learning and Teaching, 3(1), 67-78.

NHO (2013). Instruktør i larebedrift. Lcerlingens viktigste støttespiller. Oslo: NHO (Confederation of Norwegian Enterprise).

Nilsen, K.Å., \& Nore, H. (2005) Med lcerling i bedriften - en hjelp til alle med ansvar for lærlinger. Bekkestua: NKI-forlaget.

Nilsen, S.E., \& Haaland, G. (2013). Lering gjennom praksis. Innhold og arbeidsmåter i yrkesopplceringen. En grunnbok i yrkesdidaktikk. Oslo: PEDLEX Norsk Skoleinformasjon.

Nore, H. (2010). Crossing boundaries of learning. Who are the right assessors? In E. Lübcke, \& J. Burchert (Eds.), Crossing Boundaries: The multiple roles of trainers and teachers in vocational education and training (pp. 30-33.). Bremen: Trainers in Europe.

Nore, H., \& Lahn, L.C. (2013). “Vi gjør så godt vi kan”. Lokale og faglige variasjoner i arbeid med innhold og vurdering på Vg2. In H. Høst (Ed.), Kvalitet i fag-og yrkesoppleringen Fokus på skoleoppleringen. Rapport 2 Forskning på kvalitet i fag- og yrkesoppleringen (pp. 73-96). Oslo: NIFU rapport, Fafo, HiOA, UiB.

Nore, H., \& Lahn, L.C. (2014a). Innhold og vurdering i bedriftsopplæringen. In H. Høst (Ed.), Kvalitet i fag - og yrkesopplæringen. Fokus på opplæringen $i$ bedrift. Rapport 3 Forskning på kvalitet i fag-og yrkesopplceringen (pp. 85100). Oslo: NIFU-rapport, Fafo, HiOA, UiB.

Nore, H., \& Lahn, L. C. (2014b). Bridging the Gap between Work and Education in Vocational Education and Training. A study of Norwegian Apprenticeship Training Offices and E-portfolio Systems. International Journal for Research in Vocational Education and Training, 1(1), 21-34.

Reynard, R. (2007). Hybrid learning: Challenges for teachers. T.H.E. Journal: Transforming Education Trough Technology. URL: https://thejournal.com/ articles/2007/05/17/hybrid-learning-challenges-for-teachers.aspx. Accessed 30 October 2015.

Shulman, L. (1987). Knowledge and teaching: Foundations of the new reform. Harvard Educational Review, 57(1), 1-23.

Tuomi-Gröhn, T., Engeström, Y., \& Young, M. (2003). From Transfer to Boundary-crossing. In Y. Engeström, \& T. Tuomi-Gröhn (Eds.), Between school and work: New Perspectives on Transfer and Boundary-crossing, (pp.1-15). Amsterdam: Pergamon.

UHR (2006). Nasjonale retningslinjer for treårig yrkesfaglcererutdanning. In W. Veugelers, \& M.J. O’Hair (Eds.), Networking for learning and change. Network Learning for educational change (pp. 211-221). London: Open University Press.

Walker, D., \& Nocon, H. (2007). Boundary-crossing competence: Theoretical considerations and educational design. Mind, Culture, and Activity, 14(3), 178-195.

Wenger, E. (1998). Communities of practice. Learning, meaning and identity. Cambridge: Cambridge University Press. 